\title{
PROSES PUBLIC RELATIONS DALAM PROGRAM GERAKAN PUNGUT SAMPAH PEMERINTAH KOTA BANDUNG
}

\author{
Susie Perbawasari ${ }^{1}$, Diah Fatma Sjoraida ${ }^{2}$, Vidia Ayu Lestari ${ }^{3}$ \\ 1, 2, ${ }^{3}$ Program Studi Hubungan Masyarakat, Fakultas Ilmu Komunikasi, Universitas Padjadjaran \\ Jl. Raya Bandung - Sumedang KM. 21, Kec. Jatinangor, Sumedang \\ No. Telp./HP: ${ }^{1} 0811214790,{ }^{2} 0811226772,{ }^{3} 085222523502$ \\ E-mail: ${ }^{1}$ susieperbawasari@yahoo.com, ${ }^{2}$ diahfatmasjoraida@yahoo.co.id, ${ }^{3}$ vidia.ayu.lestari@gmail.com
}

Naskah diterima tanggal 21 Maret 2016, direvisi tanggal 4 September 2016, disetujui tanggal 20 September 2016

\section{PUBLIC RELATIONS PROCESS IN BANDUNG CITY GOVERNMENT PROGRAM “GERAKAN PUNGUT SAMPAH”}

\begin{abstract}
GPS program was launched in order to improve people's active participation, creating awareness of the importance of protecting the environment, and build a new culture picking up trash. Communications and delivery of messages is done through socialization programs and social media, twitter. The purpose of this study to find out the Public Relations process that consists of collecting of facts and formulation of the problem, the planning and programming, the action and communication, and the evaluation of GPS program that has been done by the organizers. This study used descriptive method. Data collected were through interviews, observation and documents. The organizers of GPS program begins by listening to the comments that raised by external parties, also took to the field looking directly environmental conditions in Bandung to collecting the facts. Organizers prepared GPS program includes the introduction of the situation, goal setting, audience definition, selection of media and techniques of Public Relations, as well as budget planning. Action taken in the program organizers GPS is acting responsive and responsible, while communication in the program include Credibility, Context, Content, Clarity, Continuity and consistency, Channel, and Capability of the Audience. Evaluation program providers include evaluation for decision-making, evaluation of the achievement of objectives, evaluation of results and impact and evaluation of the implementation.
\end{abstract}

Keywords: program, pungut sampah, environment.

Abstrak. Program GPS diluncurkan guna meningkatkan peran aktif masyarakat, menciptakan kesadaran akan pentingnya menjaga lingkungan, dan membangun budaya baru memungut sampah. Komunikasi dan penyampaian pesan program dilakukan melalui sosialisasi dan media sosial, twitter. Penelitian ini bertujuan untuk mengetahui proses PR (Public Relations) yang terdiri dari pengumpulan fakta dan perumusan masalah, perencanaan dan pemrograman, tindakan dan komunikasi, dan evaluasi pada program GPS yang dilakukan oleh penyelenggara. Metode penelitian yang digunakan adalah metode penelitian deskriptif. Pengumpulan data melalui wawancara, observasi, dan dokumen. Pengumpulan fakta yang dilakukan oleh penyelenggara dimulai dengan mendengarkan komentar dan keluhan yang dikemukakan pihak eksternal, juga turun ke lapangan melihat langsung kondisi lingkungan Kota Bandung. Penyelenggara menyusun program meliputi pengenalan situasi, penetapan tujuan, definisi khalayak, pemilihan media dan teknik-teknik PR, serta perencanaan anggaran. Aksi yang dilakukan penyelenggara dalam program GPS adalah 
bertindak responsif dan bertanggung jawab, sementara komunikasi dalam program mencakup kredibilitas, konteks, isi, kejelasan, kontinuitas dan konsistensi, saluran, dan kapabilitas atau kemampuan audience. Evaluasi yang dilakukan penyelenggara program mencakup evaluasi untuk pengambilan keputusan, evaluasi pencapaian tujuan, evaluasi atas hasil dan dampak dan evaluasi pelaksanaan.

Kata kunci: program, pungut sampah, lingkungan.

\section{PENDAHULUAN}

Sebagaimana diketahui bahwa kota sampah pernah melekat sebagai predikat dari Kota Bandung. Berdasarkan data Rencana Pembangunan Jangka Menengah Daerah - RPJMD (Peraturan Daerah Kota Bandung Nomor 3 Tahun 2014), diperkirakan sampah di Kota Bandung mencapai sekitar 357 ton perhari. Upaya pemerintah di tingkat provinsi maupun kota untuk mengatasi sampah terus berlanjut. Pemerintah Kota Bandung melakukan beberapa upaya untuk menangani masalah sampah kota, antara lain dengan menyediakan tempat sampah di sepanjang jalan, membangun kantor sampah di pasar tradisional dan menambah armada angkutan truk sampah. Namun, upaya tersebut belum cukup efektif karena masyarakat masih membuang sampah sembarangan dan tempat sampah yang disediakan di pinggir jalan justru dirusak.

Pemerintah Kota Bandung
menyadari bahwa masalah sampah ini tidak bisa diselesaikan hanya dengan pemberian fasilitas sarana dan prasarana pengelolaan sampah saja, tetapi pemerintah dan masyarakat Kota Bandung harus bekerjasama untuk menciptakan perilaku hidup bersih yang tumbuh pada diri setiap individu. Kota Bandung terus berbenah demi menjadikan kota yang bersih dan asri. Pemerintah Kota Bandung melalui Badan Pengelolaan Lingkungan Hidup (BPLH). Kota Bandung berkolaborasi dengan Bandung Cleanaction mencanangkan kampanye hidup bersih melalui program Gerakan Pungut Sampah (GPS) dengan mengajak seluruh lapisan masyarakat untuk memungut sampah di lingkungan sekitar.
GPS merupakan salah satu program dari kampanye Bandung Cleanaction. Program ini merupakan upaya Pemerintah Kota Bandung agar masyarakat membiasakan diri untuk menjaga kebersihan di lingkungannya, dengan cara menyediakan waktu sepuluh hingga tiga puluh menit sebelum melakukan aktivitas sehari-hari untuk memungut sampah di lingkungan sekitar. Gerakan ini diterapkan tiga hari dalam satu minggu, yaitu pada setiap hari Senin, Rabu, dan Jumat.

Ridwan Kamil selaku Wali Kota Bandung berharap adanya GPS ini mampu menggugah kesadaran masyarakat untuk meningkatkan kualitas lingkungan hidup. Beliau menyatakan bahwa gerakan ini merupakan gerakan perubahan kultur masyarakat Bandung agar tidak cuek terhadap kondisi lingkungan sekitar. Perubahan perilaku masyarakat untuk peduli kebersihan lingkungan menjadi tujuan dari program GPS, karena GPS itu sendiri merupakan program kampanye perubahan sosial.

Melihat GPS ini merupakan program dari suatu kampanye Public Relations (PR), pihak penyelenggara mengaplikasikan proses $\mathrm{PR}$, mulai dari pengumpulan fakta, perencanaan program, tindakan dan komunikasi, hingga evaluasi. Namun, penyelenggara belum menerapkan proses tersebut secara sistematis.

GPS yang dilakukan oleh Bandung Cleanaction merupakan public campaign yang melibatkan anak muda agar memiliki rasa tanggung jawab terhadap kotanya, sehingga Bandung menjadi bersih dengan cara yang keren dan menyenangkan. Bandung Cleanaction dibentuk oleh gabungan dari berbagai komunitas pemerhati lingkungan yang memiliki satu 
visi untuk menjadikan Kota Bandung bersih dari sampah dan menciptakan perilaku hidup bersih bagi masyarakat Kota Bandung. Selain GPS yang merupakan program aksi teladan, beberapa program lainnya yang termasuk dalam kampanye Bandung Cleanaction, antara lain sosialisasi dan diskusi yang dilakukan melalui media sosial dan Kawasan Bebas Sampah.

Kolaborasi antara pemerintah dan masyarakat dalam menumbuhkan perilaku hidup bersih penting dilakukan. Tidak hanya akan membuat Kota Bandung terbebas dari sampah, tetapi juga dapat menciptakan pribadi dan generasi yang peduli dan cinta akan lingkungan. Oleh sebab itu, penerapan hidup bersih penting untuk dilakukan demi kenyamanan dan kesehatan setiap individu. Sesuai dengan tagline dari Ridwan Kamil, yaitu "Cintai kota ini dengan aksi, cintai kota ini dengan solusi." Adanya kolaborasi antara pemerintah dan masyarakat Kota Bandung diharapkan dapat menjadikan program GPS ini sebagai solusi atas permasalahan sampah di Kota Bandung.

Berdasarkan latar belakang di atas peneliti tertarik untuk meneliti lebih jauh mengenai program GPS yang dilakukan oleh penyelenggara. Melalui penelitian ini, dapat dipahami proses PR dalam program GPS sebagai bentuk kampanye Bandung Cleanaction yang bertujuan untuk mengubah perilaku masyarakat Kota Bandung agar peduli terhadap lingkungan sekitar dan lebih mencintai Kota Bandung.

\section{LANDASAN KONSEP}

\section{Review Penelitian Sejenis}

Penelitan yang dilakukan oleh Dita Puspasari dengan judul "Kegiatan Corporate Social Responsibility Aston Bandung Hotel and Residence melalui Program Ramah Lingkungan" (Puspasari, 2014). Tujuan dari penelitian tersebut untuk mengetahui apa yang melatarbelakangi dan menjadi tujuan
Aston Bandung Hotel and Residence menerapkan Program Ramah Lingkungan sebagai kegiatan corporate social responsibility dalam membentuk identitas perusahaan menjadi green hotel dan mengetahui bagaimana pemaknaan dari berbagai perspektif dan bagaimana manajemen strategis yang dilaksanakan Aston Bandung Hotel and Residence dalam Program Ramah Lingkungan. Metode pendekatan yang digunakan adalah kualitatif dengan rancangan penelitian studi kasus. Teori yang digunakan adalah Teori Interaksi Simbolik dengan paradigma Konstruktivisme. Hasil dari penelitian tersebut adalah penerapan Program Ramah Lingkungan yang dilakukan oleh Aston Bandung Hotel and Residence dilatarbelakangi oleh komitmen yang secara tulus sebagai member of Green Hotel Association untuk menciptakan hotel yang berwawasan lingkungan. Komitmen ini diaplikasikan dan diimplementasikan sebagai wujud corporate social responsibility yang menyatu menjadi integral perusahaan.

Penelitian yang dilakukan oleh Annisa Ekalestari Putri dengan judul "Program 1000 Perahu Sapu Bersih Waduk Cirata di Desa Tegaldatar, Kecamatan Manis, Kabupaten Purwakarta" (Putri, 2013). Tujuan penelitian untuk mengetahui apa yang melatarbelakangi Badan Pengelola Waduk Cirata (BPWC) melaksanakan program 1000 Perahu Sapu Bersih Waduk Cirata. Metode pendekatan yang digunakan adalah kualitatif dengan rancangan penelitian studi kasus. Teori yang digunakan adalah Teori Stakeholder. Hasil dari penelitian tersebut yang melatarbelakangi dilakukannya program ini adalah karena Waduk Cirata terkena dampak pencemaran lingkungan akibat kegiatan dari kolam apung, industri, dan pertanian di daerah hulu, sehingga waduk mengandung bahan-bahan kimia yang bisa merusak mesin pembangkit karena adanya laju sedimentasi yang tinggi. Sedangkan latar belakang akibat diadakannya program 
pembersihan waduk secara massal adalah mengajak masyarakat dan pemangku kepentingan untuk lebih peduli terhadap kebersihan dan kelestarian Waduk Cirata. Terdapat pemahaman yang berbeda dari masyarakat Desa Tegaldatar yang lebih tertarik akan hiburan yang diberikan dan tamu undangan yang hadir, dibandingkan dengan program itu sendiri. Pelaksanaan program dilakukan melalui proses Public Relations, yaitu fact finding, planning, communicating, dan evaluating.

\section{Public Relations (PR)}

Dalam perkembangannya, humas memiliki berbagai macam definisi dan interpretasi. Cutlip et. al. dalam Morissan (2008) mendefinisikan humas sebagai usaha terencana untuk memengaruhi pandangan melalui karakter yang baik serta tindakan yang bertanggung jawab, didasarkan atas komunikasi dua arah yang saling memuaskan.

Berdasarkan definisi di atas, maka dalam menyampaikan informasi baiknya secara santun dan dapat dipertanggungjawabkan, karena humas merupakan usaha terencana untuk memengaruhi pandangan, sehingga ketika praktisi humas menyampaikan informasi dengan baik, publik akan memiliki persepsi atau opini yang positif pula terhadap organisasi tersebut.

Menurut Jefkins dalam Morissan (2008) terdapat begitu banyak definisi humas, namun ia sendiri memberikan batasan humas, yaitu sesuatu yang merangkum keseluruhan komunikasi yang terencana, baik itu ke dalam maupun ke luar antara suatu organisasi dengan semua khalayaknya dalam rangka mencapai tujuan-tujuan spesifik yang berlandaskan pada saling pengertian. Hal tersebut menunjukkan bahwa humas pada intinya senantiasa berkenaan dengan kegiatan penciptaan pemahaman melalui pengetahuan, dan melalui kegiatankegiatan tersebut diharapkan akan muncul suatu dampak, yakni perubahan yang positif.

\section{Proses Public Relations}

Menurut (Cutlip et al., 2005) PR adalah bagian proses pemecahan masalah dan perubahan organisasi yang dilakukan secara ilmiah. Praktisi PR jenis ini menggunakan teori dan bukti terbaik yang ada untuk melakukan proses empat langkah pemecahan problem sebagai berikut:

1. Mendefinisikan problem atau peluang. Langkah pertama ini mencakup penyelidikan dan memantau pengetahuan, opini, sikap, dan perilaku pihak-pihak yang terkait dengan, dan dipengaruhi oleh, tindakan dan kebijakan organisasi. Pada dasarnya ini adalah fungsi intelijen organisasi.

2. Perencanaan dan pemrograman. Informasi yang dikumpulkan dalam langkah pertama digunakan untuk membuat keputusan tentang program publik, strategi, tujuan, tindakan dan komunikasi, taktik, dan saran. Langkah ini mempertimbangkan temuan dari langkah dalam membuat kebijakan program organisasi.

3. Mengambil tindakan dan komunikasi. Langkah ketiga adalah mengimplementasikan program aksi dan komunikasi yang didesain untuk mencapai tujuan spesifik untuk masingmasing publik dalam rangka mencapai tujuan program.

4. Mengevaluasi program. Langkah terakhir dalam proses ini adalah melakukan penilaian atas persiapan, implementasi, dan hasil program. Penyesuaian akan dilakukan sembari program diimplementasikan, dan didasarkan pada evaluasi atau umpan balik tentang bagaimana program itu berhasil atau tidak.

Effendy (2002) menyatakan bahwa proses humas tidak berlangsung secara linear, melainkan melingkar. Berdasarkan pernyataan tersebut, maka jika suatu kegiatan sudah dilakukan melalui keempat tahap di atas, hasil evaluasi kegiatan tersebut diteliti lagi, direncanakan lagi, dilaksanakan lagi, dan dinilai kembali. 
Dengan demikian, setiap gagasan dapat dilaksanakan secara efektif dan efisien.

\section{Kampanye}

Kampanye merupakan kegiatan komunikasi secara terencana yang moderat, terbuka, toleran, dengan waktu terbatas atau jangka pendek, dan memiliki program yang jelas, persuasif, serta dapat diidentifikasikan secara jelas nara sumbernya (komunikator) dan selalu berkonotasi positif (Ruslan, 2005). Pengertian kampanye telah banyak dikemukakan beberapa ilmuan, ahli dan praktisi komunikasi

Rogers dan Storey dalam Venus (2009) mendefinisikan kampanye sebagai serangkaian kegiatan komunikasi yang terorganisir dengan tujuan untuk menciptakan dampak tertentu terhadap sebagian besar khalayak sasaran secara berkelanjutan dalam periode waktu tertentu. Berdasarkan definisi tersebut, kampanye harus menetapkan tujuan yang realistis sesuai situasi masalah. Perencana kampanye harus mengetahui publik yang mereka hadapi secara memadai. Apalagi jika khalayak sasaran kampanye tersebut sangat besar. Dalam hal ini, khalayak sasaran tidak boleh diperlakukan sebagai massa yang seragam, melainkan sebagai sasaran yang beragam.

\section{Gerakan Pungut Sampah}

Gerakan Pungut Sampah (GPS) adalah salah satu program dari Kampanye Bandung Cleanaction yang dibentuk oleh Pemerintah Kota Bandung berkolaborasi dengan para pemerhati lingkungan yang tergabung di dalamnya yang bertujuan agar masyarakat membiasakan diri untuk menjaga kebersihan lingkungannya dengan cara menyediakan waktu sepuluh hingga dua puluh menit untuk memungut sampah di lingkungan sekitar, jaraknya seratus hingga dua ratus meter. Gerakan ini diterapkan tiga hari dalam satu minggu, yaitu pada setiap hari Senin, Rabu, dan Jumat.
GPS pada dasarnya adalah gagasan untuk memberi ruang partisipatif masyarakat untuk bergerak masif menjaga bersih Kota Bandung. GPS diharapkan dapat memberi shock therapy bagi semua pihak, terutama warga Bandung, bahwa sampah adalah tanggung jawab bersama. Ketika bergerak gotong royong, akar persoalan terkait sampah dapat dirunut solusinya secara gotong royong pula.

\section{METODE PENELITIAN}

Metode yang dipergunakan dalam penelitian ini adalah deskriptif. Metode deskriptif menurut Sugiyono (2013) adalah metode yang digunakan untuk menggambarkan atau menganalisis suatu hasil penelitian tetapi tidak digunakan untuk membuat kesimpulan yang lebih luas.

Penelitian deskriptif mempelajari masalah-masalah dalam masyarakat, serta tata cara yang berlaku dalam masyarakat serta situasi-situasi tertentu, termasuk tentang hubungan, kegiatan-kegiatan, sikap-sikap, pandangan-pandangan, serta proses-proses yang sedang berlangsung dan pengaruh-pengaruh dari suatu fenomena (Nazir, 2009).

Penggunaan metode deskriptif dalam penelitian ini bertujuan membuat deskripsi secara sistematis, faktual, dan akurat tentang fakta-fakta dan sifat-sifat populasi atau objek tertentu. Peneliti menjelaskan secara rinci mengenai objek penelitiannya dan menjelaskan proses pengumpulan datanya. Di samping itu penelitian ini menggunakan metode deskriptif untuk memperoleh data dan fakta baik berupa kata-kata tertulis atau lisan dari berbagai sumber. Jenis data yang digunakan dalam penelitian ini adalah data yang bersifat kualitatif. Jenis data kualitatif dibutuhkan dalam penelitian ini karena dalam penelitian yang meneliti suatu proses kerja terdapat yang tidak dapat dikuantifikasikan dalam bentuk analisis statistik. Tujuan dari penelitian deskriptif ini adalah untuk 
membuat deskripsi, gambaran atau lukisan secara sistematis, faktual, dan akurat mengenai bagaimana penyelenggara pengumpulan fakta dan perumusan masalah, perencanaan dan pemrograman, tindakan dan komunikasi, dan evaluasi pada program GPS.

Populasi dalam penelitian ini adalah para pelaku yang secara langsung terlibat dalam menggagas, merancang, mengorganisasikan dan menyampaikan pesan dalam program GPS. Program GPS ini merupakan kolaborasi Pemerintah Kota Bandung melalui Badan Pengelolaan Lingkungan Hidup (BPLH) Kota Bandung dengan Bandung Cleanaction, dan teknik sampling yang digunakan dalam penelitian ini adalah purposive sampling. Subjek dipilih secara purposive berdasarkan pemahaman, waktu yang memadai, dan kesediaan mereka dalam memberikan data dan informasi. Untuk mendapatkan data yang valid, peneliti memilih narasumber yang memiliki kompetensi dan sesuai dengan kebutuhan data.

Pada penelitian ini, narasumber ditentukan sendiri oleh peneliti atas dasar kebutuhan dan kredibilitas narasumber tersebut. Beberapa kriteria atau ketentuan narasumber, antara lain sebagai berikut.

1. Mereka yang merancang ide program GPS.

2. Mereka yang terjun langsung ke lapangan dan terlibat dalam penyelenggaraan kegiatan

3. Gerakan Pungut Sampah (GPS).

4. Mereka yang terlibat dalam proses PR dan bertanggungjawab pada program Gerakan Pungut Sampah (GPS).

Dari parameter tersebut, subjek penelitian yang dianggap memenuhi kriteria telah ditetapkan adalah:

1. Hani Sumarno (Executive Board Bandung Cleanaction)

2. Hendro Talenta (Koordinator Program Bandung Cleanaction)

3. Annisa Anindita (Content Manager Bandung Cleanaction)

4. Sofyan (Kepala Bidang Program BPLH Kota Bandung)
Teknik pengumpulan data yang dilakukan dalam penelitian ini adalah melalui wawancara, observasi, studi pustaka, dan studi dokumen. Teknik analisis data yang dilakukan adalah reduksi data, penyajian data, dan penarikan simpulan. Penelitian ini dilakukan di workplace Bandung Cleanaction Jl. Cigadung Raya Barat No. 2 Bandung.

\section{HASIL PENELITIAN DAN PEMBAHASAN}

Program GPS merupakan kegiatan pungut sampah yang dikemas dengan cara menyenangkan. Terbentuknya program GPS sebagai salah satu wujud dari tagline "Cintai Kota Bandung dengan Aksi dan Solusi" yang digagas oleh Wali Kota Bandung, Ridwan Kamil. Program ini merupakan bentuk kampanye yang berorientasi pada perubahan sosial yang pelaksanaannya diawali dengan mendefinisikan masalah, yakni mengumpulkan fakta dan rumusan masalah faktual, Cutlip et al. (2009) menyatakan bahwa:

"Definisi masalah dimulai dengan melakukan penilaian tentang adanya sesuatu yang salah atau sesuatu yang seharusnya berjalan dengan lebih baik. Dalam hal ini terkandung gagasan bahwa tujuan organisasi adalah menyediakan kriteria untuk penilaian tersebut."

Pernyataan di atas menunjukkan bahwa definisi masalah menjadi dasar untuk semua langkah dalam proses pemecahan masalah dengan menentukan “Äpa yang terjadi saat ini?" Tahap ini merupakan tahap yang penting dilakukan dalam riset, tanpa rumusan masalah yang jelas maka penelitian akan kehilangan arah.

Tindakan pertama yang dilakukan penyelenggara GPS sebelum menyusun program adalah memahami situasi dan masalah yang ada. Untuk memahami 
situasi tersebut, diperlukan informasi atau data intelijen. Penyelenggara melakukan riset terlebih dahulu agar mendapatkan gambaran menyeluruh atas masalah yang tengah dihadapi. Pengumpulan fakta dilakukan melalui riset. Butterick (2013) menyatakan bahwa penelitian juga memiliki peran penting membantu mengidentifikasi dan membangun tolok ukur yang dapat digunakan untuk mengevaluasi program. Penelitian menjadi langkah paling awal yang bertujuan untuk mengetahui permasalahan lingkungan Kota Bandung, sikap dan perilaku masyarakat terhadap masalah yang terjadi.

Suriasumantri (2003) menyebutkan bahwa rumusan masalah merupakan upaya untuk menyatakan secara tersurat pernyataan-pernyataan apa saja yang ingin dicari jawabannya. Dari pernyataan tersebut, maka dapat dinyatakan bahwa perumusan masalah merupakan pernyataan spesifik mengenai ruang lingkup masalah yang akan diteliti.

Jadi langkah pertama yang dilakukan oleh BPLH Kota Bandung dan Bandung Cleanaction sebagai penyelenggara program GPS adalah mendefinisikan masalah faktual yang dirasakan. Dengan melakukan definisi masalah, penyelenggara dapat mengetahui gambaran mengenai situasi yang akan mereka hadapi ke depannya. Perumusan masalah merupakan hal utama yang ditentukan pada saat pertama kali akan dilakukan riset.

"Ya kita mengadakan riset seperti dialog dengan pemerintah. Itu dilakukan supaya kita tahu separah apa masalah sampah di Kota Bandung ini. Dan ternyata separah-parahnya masalah sampah di Kota Bandung ada 357 ton sampah yang kececer dari 1400 ton sampah perhari di Bandung. Tercecer itu nggak terangkut ya, jadi 357 ton itu nggak terangkut. Tugas yang ngangkut adalah PD Kebersihan." (Wawancara dengan Hendro Talenta pada 9 Desember 2014 di Workplace Bandung Cleanaction).
Pengumpulan fakta yang juga dilakukan oleh penyelenggara GPS dijalankan dengan turun langsung ke lapangan mendengarkan komentar, penilaian atau keluhan yang dikemukakan oleh masyarakat. Hal tersebut membuat penyelenggara mengetahui sikap dan perilaku masyarakat selama ini. Banyaknya sampah yang tercecer setiap harinya menyebabkan penumpukan sampah yang pada akhirnya mencemari lingkungan. Sofyan selaku Kepala Bidang Program BPLH Kota Bandung mengungkapkan bahwa:

"Berdasarkan RPJMD, sampah di Kota Bandung itu kira-kira mencapai 357 ton perhari. Sebetulnya begini, sampah yang ada di jalan dan sebagainya itu memang karena masyarakat sendiri belum sadar lah, belum berperilaku bagaimana seharusnya menangani sampah, sehingga dia masih membuang sampah ke sungai, ke jalan, ke tempat-tempat lain. Yang kedua, kalau tumpukan sampah itu adanya di tempat penampungan sampah sementara yang sekarang, itu memang di antaranya karena sarana masih terbatas, seperti sarana truk angkutan sampah itu masih terbatas. Kita perlu idealnya 150 unit kendaraan, tetapi yang ada hanya kurang lebih 120 unit, dan yang jalan rata-rata hanya 105 unit, jadi yang 15 itu masih keluar masuk. Nah, kemudian juga TPAnya dari Kota Bandung ke TPA sendiri cukup jauh" (Wawancara dengan Sofyan pada 17 Desember 2014 di Workplace Bandung Cleanaction).

Sofyan sebagai pihak pemerintah yang terlibat dalam program GPS mengungkapkan bahwa faktor yang menyebabkan masalah sampah di Kota Bandung ini semata-mata karena masyarakat yang belum menerapkan perilaku sadar lingkungan. Tetapi, banyaknya penumpukan sampah juga disebabkan karena kurangnya fasilitas sarana transportasi truk pengangkut sampah. Jarak Tempat Pembuangan Akhir (TPA) yang jauh juga membuat proses pengangkutan sampah menjadi lambat. 
Setelah mengetahui kondisi sesungguhnya dari masalah sampah di Kota Bandung, langkah yang dilakukan oleh penyelenggara GPS adalah melakukan analisis situasi Hasil dari riset tersebut dikumpulkan dan dianalisis menggunakan analisis situasi. Analisis situasi adalah sekumpulan hal-hal yang diketahui tentang situasi, seperti sejarahnya, kekuatan yang memengaruhinya, dan mereka yang terlibat atau terpengaruh secara internal dan eksternal (Cutlip et al., 2009).

Analisis ini bertujuan untuk mengetahui pandangan terhadap situasi yang terjadi dan bagaimana menyikapinya. Penyelenggara GPS menganalisis hasil pengumpulan fakta yang sudah dilakukan dengan menggunakan analisis SWOT. Analisis ini bertujuan untuk mengetahui pandangan terhadap situasi yang terjadi bagaimana kelebihan dan kekurangannya.

Data dan fakta yang telah dianalisis tersebut kemudian dibahas sehingga muncul masalah utama yang telah diidentifikasikan, yakni sebanyak 357 ton sampah perhari di Kota Bandung tercecer (tidak terangkut). Produksi sampah terbanyak berasal dari rumah tangga. Sampah-sampah ini tercecer di jalan, sungai, dan tempat-tempat lainnya. Penyebab utama masalah ini, antara lain rendahnya kesadaran dan kepedulian masyarakat Kota Bandung terhadap lingkungan, terbatasnya fasilitas sarana truk pengangkut sampah, dan masyarakat belum berusaha untuk mengurangi produksi sampah yang dihasilkan.

Berdasarkan hasil riset dan analisis situasi yang dilakukan, maka disusunlah suatu perencanaan program. Lattimore et al. (2004) menyatakan tentang perencanaan program PR berikut: "Public Relations effectiveness depends on planning. Understanding and developing the ability to implement an effective Public Relations plan is essential to progression from entry-level Public Relations practitioner to a top-level Public Relations manager". Berdasarkan pernyataan di atas menunjukkan bahwa perencanaan merupakan bagian yang sangat penting dalam pekerjaan PR. Adanya perencanaan membuat program lebih efektif.

Jefkins (2004) memaparkan Model Perencanaan PR Enam Langkah, antara lain (1) Pengenalan situasi; (2) Penetapan Tujuan; (3) Definisi Khalayak; (4) Pemilihan Media dan Teknik-teknik PR; (5) Perencanaan Anggaran; dan (6) Pengukuran Hasil.

Proses pengenalan situasi yang terjadi selama proses perencanaan melewati beberapa tahapan. Pada awalnya, penyelenggara GPS membahas mengenai data-data yang telah dikumpulkan, yakni:

- Rendahnya kesadaran dan kepedulian masyarakat Kota Bandung terhadap lingkungan.

- Terbatasnya fasilitas sarana truk pengangkut sampah.

- Masyarakat belum berusaha untuk mengurangi produksi sampah yang dihasilkan.

Sebetulnya ada banyak hal yang bisa dilakukan untuk mengatasi masalah sampah. Menurut Hendro, "Hal yang paling sederhana yang bisa dilakukan oleh masyarakat untuk membantu mengatasi sampah adalah dengan membuang sampah pada tempatnya" (Wawancara dengan Hendro Talenta pada 09 Desember 2014 di Workplace Bandung Cleanaction). Annisa Anindita menambahkan sebagai berikut:

"Dari hasil dialog dengan masyarakat, kita bisa simpulkan bahwa penyebab utama masalah sampah ini karena tidak adanya kesadaran dari masyarakat untuk menjaga lingkungan. Kalau memang tidak ada tong sampah di sekitar kita, apa susahnya simpan dulu sampahnya" (Wawancara dengan Annisa Anindita pada 09 Desember 2014 di Workplace Bandung Cleanaction).

Annisa Anindita menambahkan bahwa memungut sampah juga penting dilakukan agar tidak ada lagi sampah yang tercecer. Jika masyarakat terbiasa melakukan hal-hal tersebut, diharapkan masyarakat juga dapat mengurangi 
produksi sampah. Sofyan pun menyatakan hal-hal yang perlu dilakukan untuk mengatasi masalah sampah sebagai berikut:

"Kalau berkaitan dengan fasilitas sarana, pemerintah secara bertahap untuk memenuhi kebutuhan itu dengan penambahan truk angkutan. Masalah sampah ini bisa diatasi kalau ada partisipasi dari masyarakat. Ini harus kebersamaan antara pemerintah dan masyarakat. Kalau pemerintah saja, kita tidak akan bisa menciptakan itu karena akan capek saja" (Wawancara dengan Sofyan pada 17 Desember 2014 di Workplace Bandung Cleanaction).

Menurut Sofyan, masalah sampah dapat teratasi jika pemerintah dan masyarakat bekerjasama menciptakan perilaku hidup bersih. Sikap masyarakat yang tidak menunjukkan kepedulian terhadap lingkungan, seperti membuang sampah sembarangan dan membiarkan sampah berserakan akan membuat usaha pemerintah dalam menjadikan Kota Bandung bersih menjadi sia-sia. Setiap individu menghasilkan sampah dan inilah mengapa masalah sampah merupakan masalah bersama. Hani Sumarno menambahkan sebagai berikut:

"Kalau dilihat dari hasil pengamatan dan dialog dengan pemerintah, kita bisa menyimpulkan permasalahannya bahwa: (1) Masyarakat belum memiliki kesadaran untuk berperilaku hidup bersih, belum membiasakan diri untuk membuang sampah di tempatnya dan memungut sampah yang berserakan; (2) Fasilitas sarana dan prasarana yang minim dan terbatas, seperti truk angkutan sampah dan tempat sampah; (3) Masyarakat belum berusaha untuk mengurangi produksi sampah yang dihasilkan. Kalau kita dari sekarang tidak membangun sense of crisis, itu akan berapa kali lipat dua/tiga tahun yang akan datang. Sekarang aja yang diangkut sudah seribuan ton per hari, tahun depan bisa jadi dua kali lipat. Sebanyak apapun penambahan truk di PD kebersihan untuk mengangkut sampah, tapi kalau kita masyarakat ini tidak mengerem produksi sampahnya, itu nggak bakalan kekejar, tetap aja sampah bercecer itu akan ada" (Wawancara dengan Hani Sumarno pada 14 Desember 2014 di Taman Musik Centrum).

Melihat penyebab masalah sampah tersebut, pihak penyelenggara mengharapkan adanya kesadaran dan perubahan perilaku pada masyarakat. Penyelenggara menyadari bahwa permasalahan tersebut dapat diminimalisasi jika masyarakat mau gotong royong, bekerjasama dan berkolaborasi untuk menciptakan kebersihan.

Penjabaran masalah tersebut bertujuan untuk memberikan pemahaman kepada penyelenggara mengenai situasi yang sedang terjadi dan hal apa saja yang dibutuhkan untuk menyelesaikan persoalan tersebut. Program PR pada dasarnya bertujuan akhir untuk merubah sikap dan perilaku. Caranya adalah dengan melakukan pendekatan komunikasi dan ajakan kepada masyarakat melalui sebuah program kampanye.

Penyelenggara GPS kemudian melanjutkan ke langkah kedua, yakni menetapkan tujuan. Dalam tahap ini, penyelenggara menetapkan tujuan yang ingin dicapai dalam masa enam bulan pelaksanaan program. Tujuan yang ditetapkan oleh penyelenggara, yaitu meningkatkan peran aktif masyarakat dalam upaya bebas sampah sedekat mungkin. Dalam hal mewujudkan lingkungan yang bebas sampah, penyelenggara menyadari bahwa dalam hal ini perlu adanya keterlibatan masyarakat sebagai wujud cintanya terhadap Kota Bandung. Tujuan lain yaitu menciptakan kesadaran baru di segala lapisan masyarakat bahwa sampah adalah ancaman yang bila tidak diperhatikan dapat menjadi bencana. Pada tujuan ini, penyelenggara ingin membekali dan mempengaruhi pengetahuan masyarakat mengenai dampak negatif sampah dan dapak yang dapat ditimbulkan. Tujuan 
lainnya yaitu membangun budaya baru yaitu menahan sampah sampai menemukan tempat sampah, serta mengambil sampah yang berserakan sebisa mungkin. Tujuan GPS dibuat jelas dan spesifik, memungkinkan untuk dievaluasi tingkat pencapaiannya dan disusun berdasarkan prioritas, sehingga penyelenggara GPS dapat memfokuskan pekerjaan kepada satu tujuan terarah.

Langkah ketiga adalah menentukan segmentasi sasaran. Khalayak atau sasaran publik dari program GPS ini tidak ditentukan begitu saja, meskipun memang sasarannya adalah seluruh lapisan masyarakat Kota Bandung, tetapi penyelenggara menentukan pelapisan sasaran untuk mempermudah proses identifikasi dan segmentasi sasaran, Penentuan pelapisan ini pun berdasarkan riset yang ditentukan oleh penyelenggara, yaitu sasaran yang mudah secara struktural seperti pemerintah (instansi terlembaga) dan pelajar yang dijadikan sasaran yang paling potensial atau sasaran utama program GPS ini. Berbicara mengenai penentuan segmentasi sasaran, Arens dalam Venus (2009) mengatakan:

"Identifikasi dan segmentasi sasaran dilaksanakan dengan melakukan pemilahan atau segmentasi terhadap kondisi geografis (berkaitan dengan luas daerah, lokasi, jenis media serta budaya komunikasi sasaran), kondisi demografis (berkaitan dengan jenis kelamin, usia, pendidikan, pekerjaan), kondisi perilaku (berkaitan dengan status dan gaya hidup), dan kondisi psikografis (berkaitan dengan emosi dan nilai budaya yang dianut oleh publik)."

Sasaran utama program GPS ini adalah pelajar dan pemerintah, serta sasaran lapis keduanya adalah pihak swasta dan pengusaha. Penyelenggara memilih pelajar sebagai salah satu sasaran utama karena jumlah pelajar di Kota Bandung sangat banyak, sekitar 700 ribu pelajar sehingga dirasa sangat potensial. Selain itu dengan melakukan GPS, secara tidak langsung anak-anak juga mendapatkan pendidikan karakter, karena dalam prosesnya terdapat nilai-nilai yang ditanamkan kepada anak. Nilai-nilai tersebut yang diharapkan mampu membentuk pribadi anak menjadi seseorang yang peduli dan cinta lingkungan dengan melakukan aksi teladan, karena pendidikan karakter akan lebih efektif jika diterapkan sejak usia dini. Kemudian, instansi terlembaga juga dijadikan sasaran utama karena GPS menjadi aktivitas yang wajib dan rutin dilakukan di kalangan pemerintah.

Selain itu, yang menjadi sasaran lapis dua program GPS adalah pihak swasta dan pengusaha/bisnis. Pihak swasta dan pengusaha/bisnis dirasa dapat memberikan pengaruh besar kepada masyarakat dalam aktivitas pungut sampah. Apalagi jika pihak pengusaha/bisnis mau membantu mengurangi produksi sampah dengan mengurangi pemakaian plastik atau bahan lainnya yang dapat menjadi sampah pada setiap penjualan produknya. Hal ini tidak hanya akan menghindari sampah tercecer, tetapi juga akan mengurangi sampah yang dihasilkan.

Langkah keempat adalah menentukan media apa yang digunakan sebagai saluran komunikasi dan faktor pokok yang perlu dipertimbangkan dalam pemilihan media komunikasi, di antaranya jangkauan media, tipe dan ukuran besarnya khalayak, biaya, waktu, dan tujuan serta objek program.

Dengan mempertimbangkan beberapa faktor tersebut, penyelenggara GPS memilih untuk menggunakan pers lokal dan media elektronik, yaitu jejaring sosial (twitter) sebagai saluran komunikasi program GPS. Selain minim biaya, pengguna twitter saat ini juga sangat banyak, terutama kalangan remaja dan anak muda di mana mereka juga merupakan sasaran program GPS. Ridwan Kamil yang menjadi penyampai pesan pada program GPS juga aktif 
menggunakan twitter, dan beliau sering menyampaikan pesan GPS melalui twitter.

Teknis pelaksanaan aktivitas GPS juga memanfaatkan twitter sebagai media untuk mendokumentasikan kegiatan, karena tiap individu atau lembaga yang telah melakukan GPS dianjurkan untuk mendokumentasikan dan melaporkan foto kegiatan GPS mereka kepada penyelenggara melalui twitter. Penggunaan twitter dirasa paling tepat untuk melihat dan mengetahui respon masyarakat secara langsung terhadap program GPS.

Untuk pemilihan media komunikasi, media jejaring sosial menjadi pilihan penyelenggara GPS untuk menyampaikan pesan kepada khalayak yang dibidik. Media jejaring sosial dirasa tepat untuk dapat mencakup khalayak sasaran program GPS. Selain tidak berbayar, media jejaring sosial juga dianggap dapat menerima dan merespon pesan dengan cepat. Akun twitter yang aktif digunakan penyelenggara dalam program GPS ini adalah akun @GPSbdg dan @BDGcleanaction.

Selain media jejaring sosial, media lainnya yang digunakan sebagai saluran komunikasi adalah media cetak dan media online. Pihak penyelenggara GPS melakukan kerja sama (media partner) dengan media cetak lokal, seperti Pikiran Rakyat dan Tribun Jabar, juga dengan media online seperti detik.com, Harian umum berfungsi untuk menyediakan informasi secara detail dari peristiwa yang terjadi. Penyelenggara berharap dalam setiap harinya pihak media cetak maupun media online selalu menyajikan berita atau artikel mengenai sampah agar menumbuhkan kesadaran khalayak yang membacanya.

Agar program GPS ini dapat meyakinkan khalayak, pihak penyelenggara menyusun strategi dan taktik. Strategi dari program GPS adalah mengajak khalayak untuk melakukan kegiatan pungut sampah dengan cara yang menyenangkan. Kemudian taktik yang berkenaan dengan cara menyenangkan tersebut, yaitu dengan menentukan tema GPS sesuai segmentasi, pemberian reward, event, dan penggunaan twitter. Pemberian reward dimaksudkan agar para pelajar termotivasi untuk lebih semangat lagi melakukan GPS dengan rutin. Pemberian reward ini ditujukan hanya untuk sekolah-sekolah di Kota Bandung melalui GPS Pelajar. Dengan adanya reward, tiap sekolah berlomba-lomba melakukan GPS secara rutin untuk menjadi sekolah yang paling bersih.

Langkah kelima adalah merencanakan anggaran. Uang adalah salah satu sumber daya yang penting dan harus dimiliki untuk kelancaran program kampanye. Perencanaan anggaran program memunyai peran penting dalam proses evaluasi dan pengawasan fungsi manajerial. Hal lain yang juga tidak kalah penting adalah membuat rencana serta melaksanakan pengumpulan dana untuk memenuhi berbagai kebutuhan ya diperlukan dan dimasukkan ke dalam anggaran program tersebut.Tidak semua program kampanye mempunyai lembaga yang secara khusus memberikan biaya secara keseluruhan. Seperti halnya dengan program GPS, karena anggaran yang diberikan oleh pemerintah terbatas, penyelenggara GPS biasanya mendapatkan bantuan dari pihak swasta atau pengusaha/bisnis. Penyelenggara harus dapat membuat para kontributor termotivasi untuk memberikan kontribusi pada program GPS.

Menurut Shea dalam Venus (2009), ada empat elemen utama yang harus tercantum dalam rencana pengumpulan dana, yaitu besarnya dana yang dibutuhkan, waktu diperlukannya dana, pihak-pihak yang berpotensi menjadi kontributor, dan taktik pengumpulan dana. Taktik yang digunakan penyelenggara GPS untuk mengumpulkan dana dalam program Gerakan Pungut Sampah adalah Group Solicitation.

Penyusunan anggaran GPS disesuaikan dengan kebutuhan, misalnya 
untuk penyediaan fasilitas pendukung aktivitas GPS, seperti tempat sampah, trash bag, sarung tangan, hadiah dan piagam penghargaan sebagai bentuk reward, serta kebutuhan bagi penyelenggara, seperti kaos panitia, poster, dan lain-lain. Tidak ada anggaran honor untuk penyelenggara, karena program ini bersifat sukarela dan penyelenggara GPS sendiri merupakan para relawan yang ingin turun langsung menangani sampah Kota Bandung.

Langkah keenam dan terakhir adalah menentukan pengukuran hasil. Hal inilah yang tidak dilakukan oleh penyelenggara GPS dalam perencanaan. Hal lainnya yang dilakukan oleh penyelenggara pada tahap perencanaan selain Model Perencanaan PR Enam Langkah menurut Jefkins (2004) adalah alokasi waktu dan sumber daya. Alokasi waktu yang direncanakan oleh penyelenggara adalah enam bulan. Setelah itu penyelenggara berharap Program GPS tersebut dapat berkembang menjadi Gerakan Pilah Sampah, Gerakan Pengelolaan Sampah, dan yang terakhir menjadi Gerakan Punah Sampah. Di samping itu, sumberdaya juga penting untuk direncanakan agar program terlaksana dan selesai tepat pada waktunya. Dalam program GPS, sumber daya yang terlibat langsung adalah para pemerhati lingkungan, praktisi komunikasi, akademisi, dan LSM, yang kemudian didukung oleh pemerintah. Sumber daya tersebut merupakan relawan yang ingin terlibat dalam penanganan masalah sampah di Kota Bandung.

Pada tahap aksi dan komunikasi, pihak penyelenggara GPS menyusun pesan secara tepat agar dapat memengaruhi khalayak. Penyampaian pesan yang dilakukan untuk memengaruhi khalayak adalah dengan menyampaikan pesan secara menyenangkan. Dalam program GPS, sumber atau penyampai pesan yang dipilih oleh penyelenggara untuk menjadi panutan bagi masyarakat Kota Bandung adalah Wali Kota Bandung, Ridwan Kamil. Ridwan Kamil dijadikan teladan karena dianggap memiliki kredibilitas di mata masyarakat Kota Bandung, apalagi Wali Kota Bandung juga merupakan salah satu penggagas ide program GPS.

Tahap terakhir yang dilakukan adalah evaluasi. Evaluasi yang dilakukan oleh penyelenggara GPS hanya sebatas evaluasi kecil melalui diskusi, sementara evaluasi komprehensif yang melibatkan seluruh pihak yang terlibat belum pernah dilakukan. Evaluasi yang dilakukan hanya sekedar membahas pelaksanaan di lapangan, menilai teknis pelaksanaan juga sikap publik terhadap program. Hal ini diungkapkan oleh Hendro Talenta sebagai berikut:

"Evaluasi secara komprehensif belum pernah dilakukan. Pengen juga sih saya ngadain evaluasi baiknya gimana. Kalau evaluasi kecil-kecilan pernah, tapi evaluasi komprehensif dari kita, Pemkot, kewilayahan, media, itu belum dan saya kepengen evaluasi itu dilakukan sebelum tutup tahun ini. Ke depan maunya gimana itu perlu disampaikan sih. Karena kan naik turun tuh grafiknya, saya ngeliat dari twitter aja, itu masih banyak bocornya, jadi nggak mungkin diperiksain satu-satu." (Wawancara dengan Hendro Talenta pada 09 Desember 2014 di Workplace Bandung Cleanaction).

Penyelenggara GPS juga melakukan pendekatan evaluasi atas hasil dan dampak. Program GPS adalah program suatu kampanye yang dampaknya berhubungan langsung dengan pandangan masyarakat terhadap perusahaan dan juga tentunya membutuhkan sikap penerimaan yang baik dari masyarakat terhadap program. Evaluasi sikap merupakan hal wajib bagi program-program PR, karena menjalin hubungan baik dengan publik sudah menjadi tujuan pokok dari program PR. Pada pelaksanaannya, penyelenggara GPS melakukan evaluasi sikap yang sifatnya kualitatif melalui dialog dan pemantauan secara langsung, namun hasil dialog dan pemantauan tersebut tidak dikaji menggunakan indikator tertentu sehingga sulit untuk menilai bahwa 
program ini memberikan dampak yang baik bagi perusahaan dan program.

\section{PENUTUP}

\section{Simpulan}

Pengumpulan fakta telah dilakukan dengan baik oleh penyelenggara program GPS yakni diawali dengan riset yang dimulai dengan mendengarkan komentar, penilaian dan keluhan yang dikemukakan pihak eksternal. Penyelenggara mencari data dengan melakukan dialog dengan pemerintah, kemudian menggali informasi lebih dalam dengan mendengarkan komentar dan keluhan masyarakat. Selain itu, penyelenggara juga turun ke lapangan melihat langsung kondisi lingkungan di Kota Bandung.

Perencanaan yang dilakukan oleh penyelenggara program GPS telah sesuai dengan model perencanaan PR, meliputi pengenalan situasi, penetapan tujuan, definisi khalayak, pemilihan media dan teknik-teknik PR, dan perencanaan anggaran. Namun, langkah terakhir, yakni pengukuran hasil tidak dilakukan oleh penyelenggara GPS dalam perencanaan program. Tujuan yang ditetapkan oleh penyelenggara, yaitu meningkatkan peran aktif masyarakat untuk upaya bebas sampah sedekat mungkin, menciptakan kesadaran akan pentingnya menjaga lingkungan, serta membangun budaya baru menahan sampah sampai menemukan tempat sampah dan mengambil sampah yang berserakan sebisa mungkin. Yang menjadi khalayak sasaran dalam program GPS ini adalah seluruh lapisan masyarakat Kota Bandung, namun bertahap dimulai dari pelajar dan instansi pemerintah. Strategi dalam program GPS ini adalah mengajak khalayak untuk melakukan kegiatan pungut sampah dengan cara yang menyenangkan. Taktik program GPS, antara lain penggunaan twitter, pemberian reward, peluncuran tema-tema baru sesuai segmentasi, persuasi personal, dan penggunaan iklan lini bawah, berupa kaos, poster dan reklame papan. Dalam mengumpulkan dana, penyelenggara GPS menggunakan taktik Group Solicitation/Sponsorship.

Aksi yang dilakukan penyelenggara dalam program GPS adalah bertindak responsif dan bertanggung jawab. Responsif ditunjukkan dari dibentuknya program GPS sebagai wujud untuk menanggapi masalah sampah, dan bertanggung jawab ditunjukkan dari perhatian penyelenggara dalam menangani kendala pada program. Kendala yang dihadapi dalam program GPS mencakup hal pemantauan, pemberian reward, dan minimnya anggaran dana dan fasilitas. Penyelenggara GPS tidak melakukan pengawasan terhadap kinerja personel, melainkan hanya melakukan pemantauan melalui twitter atas pelaksanaan dan dampak program GPS pada masyarakat. Komunikasi dalam program GPS mencakup 7C, antara lain: Credibility, melalui Ridwan Kamil sebagai penyampai pesan pada program GPS; Context, program GPS sesuai dengan kenyataan mengenai lingkungan Kota Bandung; Content, pesan GPS relevan dengan situasi khalayak; Clarity, pesan GPS disampaikan dengan jelas dan sederhana; Continuity and consistency, program GPS berkelanjutan dan pelaksanaannya konsisten pada prinsip pelestarian lingkungan; Channel, program GPS menggunakan media sosial twitter sebagai saluran komunikasinya; dan Capability of the audience, media komunikasi dan pesan yang disampaikan pada program GPS menyesuaikan kemampuan khalayak.

Evaluasi yang paling sering dilakukan penyelenggara adalah evaluasi pelaksanaan, sementara evaluasi terhadap kinerja pelaksana tidak pernah dilakukan. Evaluasi pelaksanaan yang dilakukan penyelenggara program GPS meliputi evaluasi untuk pengambilan keputusan, berdasarkan pada pengumpulan data dan fakta yang telah diperoleh untuk menyusun program GPS. Kemudian, evaluasi pencapaian tujuan, dengan 
membandingkan hasil akhir dengan tujuan program yang ingin dicapai. Evaluasi atas hasil dan dampak, melalui dialog dan pemantauan secara langsung atas perubahan sikap maupun perilaku masyarakat. Dari evaluasi tersebut menunjukkan bahwa program GPS cukup mendapat apresiasi dari masyarakat.

\section{Saran}

Sebaiknya penyelenggara program GPS melakukan pengawasan atau pemantauan langsung turun ke lapangan untuk mengetahui perkembangan program GPS, kemudian mencatat hasilnya dalam laporan kemajuan (progress report) karena memantau hanya melalui twitter tidak dapat memberikan hasil yang valid dan akurat yang nantinya dapat memengaruhi pemberian reward pula.

Sebaiknya penyelenggara program GPS menambah media lainnya, seperti televisi dan media cetak sebagai saluran komunikasi. Hal ini disebabkan khalayak sasaran program GPS ini adalah seluruh masyarakat Kota Bandung, maka penyelenggara bisa menggunakan stasiun televisi regional dan media cetak regional sebagai saluran komunikasi program GPS. Twitter sebagai saluran komunikasi program GPS sejauh ini belum dapat mencakup seluruh lapisan masyarakat, karena tidak semua individu memiliki akun twitter, sementara khalayak sasaran program GPS adalah seluruh masyarakat Kota Bandung.

\section{DAFTAR PUSTAKA}

Butterick, K. (2013). Pengantar Public Relations: Teori dan Praktek. Jakarta: Raja Grafindo Persada.

Cutlip, S. M., Center, A. H. and Broom, G. M. (2005). Effective Public Relations: Merancang dan Melaksanakan
Kegiatan Dengan Sukses. 8th ed. Jakarta: Indeks.

Cutlip, S. M., Center, A. H. and Broom, G. M. (2009). Effective Public Relations. 9th ed. Jakarta: Kencana Prenada Media Group.

Effendy, O. U. (2002). Hubungan Masyarakat: Suatu Studi Komunikologis. Bandung: PT. Remaja Rosdakarya.

Jefkins, F. (2004). Public Relations. 5th ed. Jakarta: Erlangga.

Lattimore, D., Baskin, O., Heiman, S. T., Toth, E. L. and Leuven, J. K. Van. (2004). Public Relations: The Profession and The Practice. 5th ed. New York: McGraw Hill.

Morissan, M. A. (2008). Manajemen Public Relations: Strategi Menjadi Humas Profesional. Jakarta: Kencana Prenada Media Group.

Nazir, M. (2009). Metode Penelitian. Jakarta: Ghalia Indonesia.

Peraturan Daerah Kota Bandung Nomor 3 Tahun 2014. (2014). Rencana Pembangunan Jangka Menengah Daerah (RPJMD) Tahun 2013-2018. Bandung, Indonesia.

Puspasari, D. (2014). Kegiatan Corporate Social Responsibility Aston Bandung Hotel and Residence melalui Program Ramah Lingkungan. Universitas Padjadjaran.

Putri, A. E. (2013). Program Perahu Sapu Bersih Waduk Cirata di Desa Tegaldatar, Kecamatan Manis, Kabupaten Purwakarta. Universitas Padjadjaran.

Rakhmat, J. (2005). Metode Penelitian Komunikasi. Bandung: PT. Remaja Rosdakarya.

Ruslan, R. (2005). Kiat dan Strategi Kampanye Public Relations. Jakarta: Rajawali Pers.

Sugiyono. (2013). Memahami Penelitian Kualitatif. Bandung: Alfabeta.

Suriasumantri, J. S. (2003). Filsafat Ilmu: Sebuah Pengantar Populer. Jakarta: Pustaka Sinar Harapan.

Venus, A. (2009). Manajemen Kampanye. Bandung: Simbiosa Rekatama Media. 